\title{
TARIK-ULUR ANTARA RADIKALISME DAN MULTIKULTURALISME DALAM STUDI AGAMA DI ABAD KE 21
}

\author{
Andi Eka Putra \\ Universitas Islam Negeri Raden Intan Lampung \\ andiekaputra@radenintan.ac.id
}

\begin{abstract}
The rise of Islam mentioned by some observers of Islamic studies (Islamic studies) in the country often brings its own anomalies. The awakening often brings effects and effects that are often not expected. For example, the strengthening of notions that have not been so deeply rooted in the country, such as the understanding of terrorism and radicalism. Elsewhere, intellectuals and reviewers of the relationship of religions offer other forms such as multiculturalism. These are the two most striking faces of the Milineal or 21st century religious model: the face of radical diversity and the face of multicultural diversity. The first requires a single interpretation, the second puts forward a pluralist interpretation. If the radical face looks fierce, hard, then the multicultural face is more polite and open. Both typologies are theoretically and practically very fluid, and not as strict as the binary opposition between black and white. But both of them are quite representative of the latest variants of religion that can be found in a variety of political discourses, scientific discussions, writings in the form of news and articles in the news, Tolkshow, and serasehan. Both models are even included in the study of religious studies are almost as popular as the terms "normativity" and "bistoricity".
\end{abstract}

\section{Abstrak}

Kebangkitan Islam yang disebut-sebut oleh sebagian pemerbati studi keislaman (Islamic studies) di tanah air kerapkali membawa anomali tersendiri. Kebangkitan tersebut seringkali membawa efek dan dampak yang sering tak diharapkan. Misalnya, menguatnya paham-paham yang selama ini tak begitu mengakar di tanah air, seperti paham terorisme dan radikalisme. Di tempat lain, para intelektual dan pengkaji hubungan agama-agama menawarkan 
bentuk lain seperti multikulturalisme. Inilah dua wajah paling mencolok dari model keberagamaan abad Milineal atau abad ke-21: wajah keberagamaan yang radikal dan wajah keberagamaan yang multikultural. Yang pertama menghendaki tafsir tunggal, yang kedua mengedepankan tafsir pluralis. Jika wajah radikal tampak garang, keras, maka wajah multikultural lebih santun dan terbuka. Kedua tipologi itu dalam tataran teoritis dan praktis sangat cair, dan tidak seketat oposisi biner antara bitam dan putih. Namun keduanya cukup mewakili varian keberagamaan mutakhir yang dapat dijumpai dalam berbagai diskursus politis, diskusi ilmiah, tulisan-tulisan dalam bentuk berita dan artikel di suirat kabar, tolkshow, dan serasehan. Kedua model itu babkean masuk dalam kajian studi agama nyaris sama populernya dengan istilah "normativitas" dan "bistorisitas".

Keywords: Radicalism, Multiculturalism, 21st Century

\section{A. Pendahuluan}

Istilah "radikalisme" sudah begitu popluer dalam khazanah sosial dan studi agama. Namun istilah ini kerapkali membingungkan lantaran pemakaiannya seringkali berlebihan. Secara istilah kata radikalisme jelas bersinonim dengan kata "akar", asal, yang lebih jauh bermakna keras. Istilah radikalisme merupakan suatu paham sosial dan politik yang berwatak "keras".

Sebagai sebuah paham, ia kerapkali menimbulkan salah paham. Sebagian kalangan menganggap paham radikalisme berlawanan dengan paham multikulturalisme. Radikalisme bahkan musuh filsafat multikulturalisme. Oleh karena itu, untuk menyebarkan deradikalisasi (paham yang anti-kekerasan), maka orang perlu dibekali filsafat multikultural. Sebab yang diharapkan dari sebuah paham multikulturalisme adalah anti-kekerasan, anti penindasan dan anti penyeragaman.

Di Indonesia saat ini, terutama semenjak jatuhnya rezim Orde Baru, situasi keagamaan tampaknya mengalami "kebangkitan" di satu sisi", tetapi kebangkitan tersebut justru corak keberagamaan yang keras dan intoleran. Ada sebagian pakar menganggap bahwa saat ini Indonesia mengalami defisit atau ditandai dengan bangkitnya gerakan Islamisme dengan wajah yang kurang ramah, sensitif, intoleran. Terorisme termasuk wajah yang radikal yang mendapat momentum kebangkitan yang ikut mewarnai perbincangan publ;ik di abad ke-21 ini. 
Dahulu, pada masa Orde Baru, situasi dan suasana keberagamaan di Indonesia sering tampak 'aman-aman saja", "damaidamai saja", dan yang terdengar adalah seruan "kerukunan antarumat beragama". Kini suasana itu seperti berubah menjadi seratus derajat lantaran wajah Islam yang tampil tampak lebih garang, lebih keras, kurang toleran dan kurang bersahabat dengan aneka perbedaan paham dan aliran. Padahal dahulu Indonesia dianggap oleh para pengamat dan peneliti luar sebagai situasi yang penuh keterbukaan, kerukunan, toleransi dan perdamaian. Terjalin harmonisasi antarumat beragama di tengah-tengah masyarakat Orde Baru yang aman dan terkendali.

Barangkali lantaran rezim Soeharto menerapkan peraturan sangat ketat terhadap berbagai aliran agama dan kepercayaan sehingga tidak memungkinkan gerakan radikal muncul ke panggung politik tanah air dan mendominasi wacana keislaman. Justru yang munc ul adalah benih-benih multikulturalisme dalam bentuk perbincangan dan diskusi mengenai pluralisme, liberalisme dan sekularisme. Kuatnya barisan militer pada masa Soeharto juga membuat gerakan garis keras sulit muncul karena akan berhadapan langsung dengan ABRI sebagai pemegang kendali.

Tapi kini situasi politik tanah air sangat cair dan terbuka. Kebebasan betul-betul membawa efek yang sulit membendung setiap paham keagamaan dan politik yang muncul dan mengekspresikan diri. Setiap paham bebas bergerak dan bebas berdiri dan mencari pengikut. Bahkan ada trend kebangkitan gerakan Islam internasional yang memengaruhi gerakan Islam di Indonesia yang semula ramah, inklusif, perlahan-lahan menjadi keras dan militan.

Beberapa pengamat melihat mengapa pada masa Orde Baru corak keberagamaan lebih terbuka dan toleran, paham inklusivitas dan liberal cukup berkembang dengan baik dan menjadi bahan diskusi di kampus-kampus, itu karena corak politik otoritarian memang menghendaki kehidupan yang inklusif, damai, tidak gaduh, dan dilarang berseteru lebih kritis dan terbuka. Apa yang justru diuntungkan pada masa Orde Baru yang otoriter adalah kaum pembaru dan gerakan Islam toleran, gerakan Islam berkemajuan, gerakan inklusif dan gerakan Islam moderat yang mewacanakan pluralisme, liberalisme, dan multikulturalisme. Sementara gerakan radikal tak begitu terlihat, bahkan sulit muncul ke permukaan. 
Diskursus keislaman di kampus-kampus didominasi oleh Islam inklusif, Islam pluralis dan kerukunan antarumat beragama serta toleransi.

Fakta lain juga memperlihatkan bahwa kebangkitan Islam pasca-Orde Baru merupakan kebangkitan wajah Islam yang pemarah, sensitif, konservatif dan fundamentalis. ${ }^{1}$ Bahkan ada pula hasil penelitian menyebutkan adanya Islam garis keras di Indonesia yang diwakili oleh gerakan Islam transnasional yang masuk ke wilayah Indonesia yang mempengaruhi banyak organisasi Islam pasca-Orde Baru. $^{2}$

Hampir semua peneliti mengamati situasi keagamaan di Indonesia pasca-Orde Baru yang semakin menuju arah konservatif dan radikal. Ada kekhawatiran berlebihan jika paham keterbukaan, demokrasi, kerukunan, akan "kalah" oleh paham "radikal" dan intoleran. Gejala-gejala pemaksaan kehendak, klaim kebenaran paham, tafsir tunggal, pandangan yang sempit, terlihat mendominasi wacana diskusi di kampus-kampus dan perguruan tinggi Islam seperti Stain, IAIN dan UIN.

Kebangkitan Islam menjadi anomali karena yang bangkit adalah corak dan paham keislaman yang tunggal, yang propengkafiran dan pemurtadan lawan yang tidak sepaham dan sehaluan. Ini sungguh amat merugikan dan mengerikan bagi proses bermasyarakat di Indonesia saat ini.

Kebangkitan radikalisme juga menjadi perhatian serius pemerintah, karena gerakan ini berkembang setelah adanya fenomena kekerasan di Indonesia yang dilakukan oleh beberapa organisasi kemasyarakatan (ormas) yang disebabkan oleh sikap yang kuat dan

${ }^{1}$ Beberapa peneliti tersebut di antaranya Martin van Bruinnessen dalam buku yang di editorinya, Coservative Turn: Islam Indonesia dalam Ancaman Fundamentalisme, (Jakarta: Mizan, 2014), Budhy Munawar-Rachman, Sekularisme, Liberalisme dan Pluralisme, (Jakarta: Grasindo, 2010), Karlina Supelli, Dari Kosmologi ke Dialog: Mengenal batas Pengetabuan, Menentang Fanatisme, (Bandung: Mizan, 2011), Ariel Heryanto, Identitas dan Kenikmatan, (Jakarta: KPG, 2015).

${ }^{2}$ Penggunaan istilah untuk radikalisme memang bermacam-macam. Yang secara konsisten menggunakan istilah Islam garis keras adalah hasil penelitin yang diidetor oleh Abdurrahman Wahid berjudul, Ilusi Negara Islam: Ekspansi Gerakan Islam Transnasional di Indonesia, (Jakarta: The Wahid Institute, Al-Maa'rif, Gerakan Bhineka Tunggal Ika, 2009, h. 115). 
kecenderungan orang-orang Islam untuk memaksakan ajaran dan pahamnya kepada pihak lain melalui jalan yang keras. ${ }^{3}$

Beberapa koran nasional dan lokal akhir-akhir ini masih terus memberitakan tentang upaya pemerintah membendung gerakan radikalisme di Indonesia karena gerakan ini semakin meluas dan meresahkan masyarakat. ${ }^{4} \mathrm{Hal}$ ini menunjukkan bahwa gerakan radikalisme agama benar-benar mesti diwaspadai dan mesti menjadi kesadaran bersama umat Islam untuk membentengi kaum muslim dari pengaruh ajaran radikal.

Apa sesungguhnya yang dimaksud radikalisme? Adakah gerakan radikalisme agama yang selama ini begitu semarak diberitakan? Kalau ada, apa yang melatbelakangi munculnya gerakan tersebut? Bagaimana peran para mubalikh atau penyluh agama untuk membendung arus gerakan radikalisme agama tersebut?

Beragam pertanyaan itu akan coba dicarikan jawabannya melalui makalah singkat ini. Jawaban-jawaban atas berbagai pertanyaan itu tentu lebih bersifat teaoritis dengan berangkat dari fenomena umum yang muncul lewat berbagai berita, siaran, tulisan dan penelitian. Makalah ini sama sekali tidak mengangkat fakta lapangan dengan riset yang terfokus pada fenomena kawasan tertentu.

\section{B. Melacak Akar Sejarah Radikalisme di Indonesia}

Di muka telah disinggung bahwa kata radikal artinya akar, atau asal. Secara bahasa, radikalisme adalah suatu paham yang menjunjung akar kesejarahan yang dicirkan oleh pandangan yang memaksakan kehendak, memaksakan paham sendiri, bersifat tertutup, mengaku satu-satunya sebagai yang murni dan paham lain

${ }^{3}$ A. Fadlan, Islam dan Radikalisme di Indonesia, (Jakarta: LIPI Press, 2005),

4 Kompas menurunkan berita berjudul "Bin dan Kepolisian terus Mengawasi gerakan radikal di Indonesia", Kompas Senin 16 Mei 2016 h. 14, Republika menurunkan berita berjudul "Radikalisme dan Komunisme Tetap sebagai bahaya laten”, Republika Senin 16 Mei 2016 h. 4, Lampung Post, "Organisasi Anti Pancasila Ancam NKRI", Rabu 11 Mei 206 h. 6 dimana didalamnya disebutkan bahaya radikalisme dan komunisme. 
salah atau menyimpang, yang gerakan-gerakannya melahirkan kekerasan. ${ }^{5}$

Kata radikal sendiri dalam bahasa Inggris mengandung dua pengertan: (1) bertindak radikal dan dapat juga berarti (2) sampai ke akar-akarnya. Kata radikal yang berarti sampai ke akar-akarnya, biasanya digunakan dalam diskursus filsafat, terutama dalam mendefinisikan kata filsafat itu sendiri. ${ }^{6}$ Tapi arti kata radikal yang dimaksud dalam makalah ini mengacu kepada makna yang pertama (bertindak radikal).

Berangkat dari pemaknaan semacam itu, dapat ditegaskan bahwa aliran yang disebut dengan radikalisme itu adalah suatu aliran atau paham yang memaksakan ajarannya melalui jalan kekerasan dan menimbulkan keresahan kepada banyak orang. Di sini radikalisme menekankan akar kesejarahan sebagai satu landasan gerakan mereka yang otentik. Paham radikal bertujuan memaksakan kehendak agar paham mereka bisa diterima sebanyak mungkin oleh kaum muslim. Mereka sering melakukan seeping, tindakan melanggar hukum, kekerasan, dan dalam setiap aksinya nyaris tanpa kompromi.

Paham radikalisme sebenarnya bukan fenomena baru dalam wilayah keagamaan di berbagai belahan dunia. Hampir semua agama memiliki paham radikal, sebagimana semua agama memiliki paham yang toleran dan terbuka. Dua tipe dan model keberagaam ini sangat sederhana dan paling mudah dipetakan dalam kajian sosial dan studi agama.

Dalam Yahudi, Kristen dan Islam awal sudah terdapat bibtbibit radikalisme. Dalam Islam ditunjukkan oleh kecenderungan aliran Khawarij yang keras, yang tidak sepaham dengan mereka akan dicap kafir dan darahnya halal dibunuh. Inilah akar tertua radikalisme dalam Islam. Begitu juga dalam Yahudi dan Kristen, terdapat aliran radikall yang menekankan kehendak untuk kembali kepada

${ }^{5}$ Hamid Algar, Wabhabisme: Sebuah Tinjauan Kritis, terj. Rudy Harisyah Alam, (Jakarta: Paramadina, h. 19.

${ }^{6}$ Nasaruddin Umar, Deradikalisasi Pemahaman Al-Qur'an dan Hadis, (Jakarta: PT Elex Media Komputindo, 2014), h. 4. 
kemurnian kitab suci dan dalam setiap aksinya menimbulkan kekerasan. ${ }^{7}$

Munulnya gerakan radikalisme keagamaan di Indonesia tidak terlepas dari pengaruh gerakan keagamaan internasional. Menurut Deny Suwito, lahir dan berkembangnya radikalisme di Indonesia tidak bisa dilepaskan dari pengaruh radikal Islam di Timur Tengah sebagai reaksi atas kekalahan politik Islam yang menyakitkan. ${ }^{8} \mathrm{Jadi}$, munculnya radikalisme tidak murni karena masalah teologi, melainkan ada unsur pertarungan politik di baliknya.

Akar radikalisme agama sebetulnya sudah sangat tua, termasuk di negeri ini. Menurut hasil penelitian Muhammad Wildan terhadap gerakan radikal di Solo, Jawa Tengah, munculnya sejumlah kelompok Islam radikal akhir-akhir ini dilatarbelakangi oleh respon hegemoni Amerika Serikat dalam kebijakan luar negerinya yang memusuhi Islam. Sebagai negara Super Power Amerika Serikat telah memancing kemarahan sejumlah organisasi Islam akibat kebijakannya menduduki dan memerangi bangsa Irak, Afganistan, dan mendukung Israel untuk menghancurkan Palestina. ${ }^{9}$

Sebagian besar aktivis gerakan Islam radikal juga menunjuk Barat-terutama Amerika Serikat-sebagai penyebab suburnya gerakan radikalisme Islam. Barat telah melakukan politik standar ganda dan merugikan umat Islam dalam berbagai kebijakannya di Timur Tengah. Islam digambarkan oleh pers Amerika sebagai agama teror dan kekerasan. Film-film dibuat untuk menggambarkan nabi Muhammad sebagai teroris dan al-Qur'an mengajarkan kekerasan dan pembunuhan.

Selain itu, penyebab munculnya radikalisme juga ditengarai oleh kecenderungan umat Islam sendiri, teruatama yang terdidik dan terpelajar, berorientasi pada paham sekular, pluralis dan liberalis yang semuanya merupakan dan dianggap pengaruh dari Barat. Proses

7 Penelitian mengenai radikalisme atau fundamentalisme dalam ketiga agama besar itu, lihat Karen Amstrong, Berperang Demi Tuban: Fundamentalisme dalam islam, Kristen, dan Yabudi, terj. T. hermaya, (Bandung: Mizan, 2013).

${ }^{8}$ Deny Suwito, Radikalisme di Dunia Islam, (Jakarta: CMM, 2005), h. 164.

9 Muhammad Wildan, "Memetakan islam Radikal: Studi Atas Suburnya Gerakan Islam radikal di Solo, Jawa Tengah”, dalam Martin van Bruinessen (ed), Conservative Turn: Islam Indonesia dalam Ancaman Fundamentalisme, (Bandung: Mizan, 2014), h. 294 
modernisasi juga kerapkali dijadikan alasan munculnya berbagai gerakan Islam radikal.

Dalam studi radikalisme di Indonesia berkembang sejumlah teori tentang latar belakang muncul dan berkembangnya paham radikal di Indonesia, di antaranya yaitu:

Azyumardi Azra berpendapat muncul dan berkembangnya radikalisme Indonesia disebabkan oleh faktor internal dan eksternal. Fakor internal yakni adanya penyimpangan norma-norma dalam pemahaman pesan dan kandungan Kitab Suci. Faktor eksternal karena dunia smakin berkembang ke arah sekular sehingga menjadi ancaman yang serius bagi iman. ${ }^{10}$

Kemunculan radikalisme merupakan respon dari kondisi yang sedang berkembang di dunia, juga adanya keyakinan yang kuat akan kebenaran program dan ideologi yang mereka anut. ${ }^{11}$

Dari beberapa pendapat di atas dapat dipahami bahwa kemunculan gerakan radikalisme di Indonesia disebabkan oleh faktor dari dalam pelaku itu sendiri dan faktor eksternal dalam bentuk kekecewaan politik ketika melihat perubahan dan perkembangan dunia yang semakin sekular dan jauh dari nilai-nilai Islam.

\section{Memposisikan Dakwah dan Studi Agama di Abad Ke-21}

Dakwah saat ini mengalami kebangkitan dan gairah baru. Banyak tampil dai dan mubalikh muda dan langsung mencatatkan dirinya sebagai pendakwah yang populer baik di televisi maupun di media sosial. Kebangkitan dakwah Islam mendapat tantangan yang serius di tengah kehidupan berbangsa yang sedang mengalami masa transisi dari ketertutupan Orde Baru menjadi keterbukaan Orde Reformasi.

Tantangan itu seringklali berbentuk menguatnya paham radikalisme dan kekerasan atas nama ajaran agama, yang sebagian didukung oleh para penceramah dan mubalikh. Beberapa mubalikh

10 Azyumardi Azra, "Mereka Mengambil Alih Penegakan Hukum", Republika 2 Maret 2002, h. 5.

${ }^{11}$ Bachtiar Effendi, Radikalisme: Sebuah Pengantar, (Jakarta: PPIM IAIN, 1998), h. xvi-xviii. 
menyerang paham-paham keterbukaan seperti plutraralisme, liberalisme dan sekularisme dengan membangun sinonim yang negatif seperti Sepilis. Beberapa dai juga menyerang habis paham kebebasan dan lesbian, gaya dan LGBT.

Sebagai agama dakwah, Islam jelas tidak mungkin meninggalkan kewajiban untuk terus menyeru pada umatnya karena esensi ajaran Islam terletak pada penyebaran agama ini di masa lalu. Namun demikian, di tengah tantangan kehidupan yang majemuk dan plural, dakwah dapat dilakukan melalui agenda-agenda dan materi yang lebih berhubungan dengan relasi sosial antarumat beragama, bukan melulu propaganda di media sosial.

Sementara itu, studi agama tampak kurang mengalami gairah. Karya-karya intelektual yang mengedepankan model keberagamaan yang sejuk jauh berkurang dibandingkan di masa Orde Baru. Tulisantulisan yang menyerukan keterbukaan jauh lebih sedikit dari tulisan yang menyebarkan propaganda dan radikalisme, terutama di ruang publik. Para peneliti profesional jarang menghasilkan karya atau makalah yang punya pengaruh besar sebagaimana dulu dilakukan oleh A. Multi Ali, Harun Nasution, Abdurrahman Wahid, Nurcholish Madjid, Munawir Sadjali, Johan Effendi, Komaruddin Hidayat, Azyumardi Azra, dan lain sebagainya.

Sebagai sebuah paham, pluralisme atau multikulturalisme adalah kosakata yang belakangan ini kembali hangat dibicarakan di mana-mana seiring dengan menguatnya arus radikalisme dan terorisme. Padahal para intelektual yang nama-namanya disebut di atas memiliki perhatian yang sama dengan isu ini, hanya saja kini semakin sedikit yang melanjutkan.

Perbincangan dan pembicaraan seputar kedua tipologi keberagamaan itu semakin hari semakin menguat dan meruncing, tapi minus penelitian ilmiah. Kedua tipe itu terjadi tarik-ulur disebabkan oleh beragam faktor pemicunya.

Di tingkat internasional, muncul isu yang dikampanyekan oleh media Barat bahwa Islam agama teror dan menebar kekerasan di segala bangsa. Di tingkat nasional, muncul beberapa konflik dan belakangan lahirlah fatwa MUI tahun 2005 lalu yang mengharamkan sekularisme, liberalisme, dan pluralisme sehingga berdampak meredupnya wacana ini di kampus-kampus Islam seperti IAIN dan 
UIN.

Menurut Budhy Munawar-Rachman, fatwa MUI yang mengharamkan ketiga aliran yang selama ini diperjuangkan oleh kaum pembaru tersebut telah memporak-porandakan begitu banyak kajian dan pemikiran yang selama ini memperbolehkan pluralisme di Indonesia berkembang. Fatwa MUI juga melanggar asas-asas dan basis moral keislaman universal, karena fatwa MUI ini sangat eksklusif, tidak pluralis, bahkan cenderung diskriminatif. ${ }^{12}$

Beberapa tahun lalu juga banyak pengamat Islam yang tersentak kaget ketika membaca buku paket Pendidikan Agama Islam (PAI) dan Budi Pekerti kelas XI terbitan resmi Kementerian Pendidikan dan Kebudayaan (Kemendikbud) yang terdapat kalimat "Pembunuhan terhadap orang yang menyembah selain Allah atau musyrik boleh dilakukan". ${ }^{13}$ Kalimat ini jelas mengarahkan pada paham radikalisme agama yang bertentangan dengan konstitusi yang menekankan asas penghargaan atas berbabagai macam agama, keyakinan, budaya dan golongan.

Selain itu, terdapat dugaan kuat adanya proses infiltrasi paham radikal dalam rumusan tersebut. Padahal dalam beberapa dasawarsa terakhir, bangsa Indonesia sedang menggalakkan kerukunan hidup antarumat beragama, penghargaan atas pluralitas agama, budaya dan etnik serta usaha membangun masyarakat multikultural yang sungguh-sungguh dalam rangka memasuki pergaulan dunia internasional yang semakin mengglobal.

Di sini pentingnya pemahaman terus-menerus perihal pluralisme sebagai basis dan titik-tolak berbangsa dan bernegara. Sebab, sebagaimana dikatakan Budhy Munawar-Rachman, pluralisme di samping mengakui perbedaan juga menganjurkan dialog yang dialogis. Dalam proses dialog tersebut semua saling memahami dan mengapresiasi. ${ }^{14}$

Disinilah arti penting dai dan penyuluh agama yang berwawasan studi agama dan hubungan antar-agama. Yang

${ }^{12}$ Budhy Munawar-Rachman, Sekularisme, Liberalisme dan Pluralisme, (Jakarta: Grasindo, 2010), h. 7

${ }^{13}$ Dikutip dari berita harian nasional Kompas, "Buku Pendidikan dan Budi Pekerti yang Meresahkan”, 12 Noveber 2014

${ }^{14}$ Budhy Munawar-Rachman, Sekularisme, Liberalisme..., h. 152 
dibutuhkan adalah dai dan mubalikh kampus yang berwawasan multikultural. Mereka inilah yang berperan menyampaikan ajaran Islam dengan sejuk dan ramah, juga sebagai pengajak ke jalan kedamaian dan kerukunan. Melalui penyuluhan agama diharapkan arus gerakan radikal dapat dibendung dan diminimalisir, bukan dibesar-besarkan apalagi didukung oleh para dai dan ustad serta para penyuluh agama di lapangan.

Hal ini tentu menuntut para penyuluh agama untuk bersikap dewasa dalam beragama dan peka dan waspada dalam melihat perkembangan radikalisme di lapangan. Tugas pendakwah dan penceramah agama dilaksanakan oleh seorang Penyuluh Agama Islam, yang dalam perkembangannya sudah banyak dilakukan organisasi dan kelembagaan da'wah, bahkan pembinaan kelembagaan penyuluh agama juga sudah menjadi kebijakan pembangunan agama yang dilakukan secara terprogram dan berkelanjutan oleh masyarakat maupun pemerintah. Namun sejalan dengan dinamika sosial dan kultural sebagai dampak pembangunan keagamaan, maka dalam pembinaan kehidupan keagamaan dibutuhkan kajian tentang da'wah secara luas dan mendalam yang terkait isu-isu radikalisme, terorisme dan kekerasan atas nama agama.

Penyuluh Pembangunan Agama Islam adalah mitra bimbingan Direktorat Jenderal Bimbingan masyarakat Islam yang diharapkan mampu menjadi garda depan dalam mendewasakan umat Islam terhadap pemahaman agama. Lembaga penyuluh agama dapat menjadi ujung tombak dalam pelaksanaan tugas membimbing umat Islam dalam mencapai kehidupan yang toleran, bermutu dan sejahtera lahir batin.

Peran para penceramah mulanya dilaksanakan oleh para pemuka agama yaitu Ulama, Muballigh, Da'i atau Kiai yang menyampaikan langsung kepada masyarakat. Kegiatan yang dilakukan adalah pengajian, tabligh, dakwah di rumah-rumah, langgar, masjid maupun tempat-tempat lainnya. Materi yang disampaikan dalam penyuluhan Agama Islam selain khusus tentang agama juga disampaikan tentang masalah kemasyarakatan dan bimbingan dalam kehidupan sehari-hari. ${ }^{15}$

${ }^{15}$ Faiz Fayadi dkk., Petunjuk. Teknis Pelaksanaan Jabatan Fungsional Penyuluh Agama, (Jakarta: Direktorat Jenderal Bimbingan Masyarakat Islam, 2012), h. 8 
Dengan demikian, para dai adalah pembimbing umat menuju jalan yang lurus, menuju proses deradikalisasi agama. Mereka membimbing umat Islam dalam rangka pembinaan mental, moral dan ketaqwaan kepada Tuhan Yang Maha Esa, Allah SWT, serta menjabarkan segala aspek pembangunan melalui pintu dan bahasa agama. Penyuluh Pembangunan Agama menjadi penerang kegelapan bagi masyarakat mengenai prinsip-prinsip dan etika nilai keberagaman dalam kehidupan sosial-kemasyarakatan.

Di samping itu mereka merupakan ujung tombak dari Kementerian Agama dalam pelaksanaan tugas membimbing umat Islam dalam mencapai kehidupan yang bermutu dan sejahtera lahir batin. Hasil akhir yang ingin dicapai dari penyuluahan agama pada hakekatnya ialah terwujudnya kehidupan masyarakat yang memiliki pemahaman mengenai agamanya secara memadai yang ditunjukkan melaui pengamalannya yang penuh komitmen dan kosisten disertai wawasan multikultural, untuk mewujudkan tatanan kehidupan yang harmonis dan saling menghargai satu sama lain.

Penyuluhan agama, sejauh ini, merupakan usaha penyampaian ajaran Islam yang hanif dan santun kepada umat manusia oleh seseorang atau kelompok orang secara sadar dan terencana, dengan berbagai metode yang baik dan sesuai dengan sasaran penyuluhan, sehingga berubahlah deadaan umat itu kepada yang lebih baik, untuk memperoleh kebahagiaan di dunia dan di akhirat.

Beban tugas penyuluh agama dalam masa pembangunan dewasa ini, dituntut agar mampu menyebarkan segala aspek mehdupan sosial yang kondusif, memberkan arah dan motivasi bagi proses deradikalisasi ajaran agama. Salah satu tugas penyluh agama, kata Nasaruddin Umar, yaitu menyampaikan proses deradikalisasi pemahaman al-Qur'an dan hadits sehingga terwujud kehidupan beragama yang damai dan toleran. ${ }^{16}$

Dalam konteks ini, penyuluh agama harus dapat memahami materi da'wah, menguasai betul metode dakwah dan teknik penyuluhan, sehingga diharapkan seorang penyuluh agama dapat mencapai tujuan da'wah yaitu dapat mengubah masyarakat sasaran kearah kehidupan yang lebih baik dan sejahtera lahir maupun batin. Wajar kiranya penyuluh agama diharapkan dapat berperan pula sebagai motivator pembangunan. Tugas penyuluh agama sangat

${ }^{16}$ Nasaruddin Umar, Deradikalisasi..., h. 310 
penting karena pembangunan tidak semata-mata membangun manusia dari aspek lahiriah dan jasmani saja, melainkan juga membimbing dan membangun aspek rohaniah, mental spiritualnya yang dilaksanakan secara simultan.

Sejumlah pertanyaan fundamental perlu diajukan di sini bagaimana Islam sebagai agama dakwah menangani isu pluralisme akhir-akhir ini yang semakin semarak. Apakah agama, khususnya bidang dakwah, kompatibel dengan pluralisme? Apakah syiar Islam melalui dakwah tidak bertentangan dengan masyarakat pluralis? Para ahli dan tokoh agama pada umumnya merespon pertanyaanpertanyaan tersebut secara positif. Mereka mengakui dan percaya bahwa kemajemukan dan keberagaman manusia adalah niscaya dan dakwah sama sekali tidak bertentangan dengan masalah pluralisme.

Bahkan, dakwah dapat menjadi sarana dan jalan untuk menyampaikan dan mensosialisasikan isu-isu pluralisme. Dakwah Islam dapat menjadi tulang punggung bagi pemerdayaan umat mengenai perbedaan-perbedaan manusia sebagai realitas yang tidak mungkin dinafikan oleh apa pun dan siapa pun. ${ }^{17}$

Saat ini yang dibutuhkan adalah redefinisi dakwah yang bukan sekedar tugas menyampaikan pesan agama, melainkan juga pendewasaan umat beragama dalam bentuk keasadaran akan kebhinekaan bangsa Indonesia. Jika kita menggali sejarah bangsa Indonesia di masa lalu, maka di sana akan ditemukan sejarah tentang bagaimana mengelola kemajemukan dan multikulturalitas sebagai suatu langkah membangun kesetaraan berbangsa di tengah berbagai macam perbedaan. Semangat plural dan multikultural inilah seperti mendapat tantangan terus dari paham radikal yang menginginkan masyarakat Indonesia menjadi masyarakat monokultural, masyarakat yang hanya terdiri dari satu budaya, satu peradaban, dan satu agama. Mereka menginginkan tegaknya negara Islam padahal sejarah Indonesia telah mempertegas negara kesatuan berdasarkan Pancasila.

Namun masih banyak yang tampaknya merasa "alergi" dengan negara multikultur. Padahal negara yang menjunjung semangat multikultural inilah yang justru berpijak dari sejarah nyata, bukan khayalan dan utopia. Lawrence A. Blum, dalam pengantar

${ }^{17}$ Husein Muhammad, Mengaji Pluralisme Kepada Mahaguru Pencerahan, (Bandung: Mizan, 2011), h. 4 
buku suntingan Larry May, Shari Collins-Chobanian dan Kai Wong, , Etika Terapan: Sebuah Pendekatan Multikultural, merumuskan falsafah multikultural ke dalam tiga kerangka dasar. Pertama, multikultural dan multikulturalisme pada dasarnya merupakan sebuah pemahaman, penghargaan dan penilaian atas budaya seseorang. Kedua, multikulturalisme sebagai upaya penghormatan serta keingintahuan tentang budaya serta etnis orang lain. Ketiga, multikulturalisme mencakup upaya untuk 'mencoba melihat bagaimana kebudayaan yang ada dapat mengekspresikan nilai bagi anggota-anggotanya sendiri dan orang lain. ${ }^{18}$

Dari ketiga kerangka dasar filosofi pluralismemultikulturalisme tersebut, dapat diambil pemahaman, bahwa pluralisme dan multikulturalisme merupakan aliran filsafat yang memfokuskankan perhatian pada keaneka-ragaman dan bagaimana menjadikan keragaman yang ada sebagai aset suatu bangsa untuk dikelola dengan baik. Tujuannya yaitu bagaimana masing-masing individu dalam suatu bangsa dapat mengekspresikan nilai bagi anggota-anggotanya sendiri dan orang lain secara merdeka.

Jika persoalannya adalah bagaimana menempatkan keragaman sebagai aset bangsa yang dapat dikelola demi tegaknya nilai-nilai bersama suatu bangsa di tatanan pluralitas budaya, maka dakwah bukan halangan bagi wacana pluralisme dan multikulturalisme. Pluralisme juga bukan sekadar tema yang harus dipelajari, dipahami, atau dihayati di lingkungan pendidikan, tetapi perlu didakwahkan, disampaikan dengan tujuan agar umat Islam saling menghargai dan hidup rukun dalam bingkai kebhinekaan. Tetapi, lebih dari itu, bagaimana mengamalkan nilai-nilai pluralis yang menghargai kemajemukan budaya dan manusia tersebut dalam laku kehidupan sehari-hari umat Islam.

Persoalan yang terakhir inilah yang agaknya perlu kita tekankan dalam pembahasan setiap gagasan tentang dakwah di tengah pluralisme berbangsa. Jika ditarik dalam konteks praksis dakwah Islam, semangat pluralisme-multikulturalisme yang akhirakhir ini mulai sering dibicarakan dan diseminarkan, maka filosofi di

${ }^{18}$ Larry May, Shari Collins-Chobanian dan Kai Wong, Etika Terapan: Sebuah Pendekatan Multikultural, Terj. Imron Rosyidi, (Yogyakarta: Tiara Wacana, 2001), h. 2 
atas mesti diturunkan ke dalam tingkat praksis dimana para dai sudah semestinya memiliki wawasan pluralis dan multikulturalis sebelum terjun ke lapangan. Artinya, materi dakwah dan manajemen dakwah mesti dirancang dan didesain secara sungguh-sungguh dalam konteks mempersiapkan para jamaah agar memiliki wawasan pluralisme sekaligus wawasan kebangsaan. Di sini yang diperlukan adalah bagaimana bersikap terhadap perbedaan, apa yang mesti dilakukan dalam menghadapi pluralitas kehidupan (baik pluralitas etnik, budaya, golongan, maupun pluralitas bahasa dan suku bangsa), dan bagaimana mengelola manajemen konflik akibat perbedaan melalui pendekatan multikultural.

\section{Penutup}

Tidak bisa dipungkiri bahwa perkembangan akhir-akhir ini memperlihatkan bahwa Islam telah diberi stigma negatif terkait dengan banyaknya tindakan radikal, sweeping, kekerasan. Berbagai peristiwa dan kasus bom yang terjadi belakangan ini sering dihubunghubungkan dengan gerakan radikalisme. Padahal Islam sendiri sama sekali tidak mengajarkan umatnya untuk melakukan tindakan radikal di luar batas nalar kemanusiaan. Islam datang justru membawakan panji-panji kedamaian dan menyerukan hidup berdampingan dengan komunitas agama lain.

Menghadapi citra dan stigma negatif terhadap Islam sebagai agama radikal itu, dibutuhkan peran aktif para penceramah Islam yang juga konsen di bidang studi agama atau studi hubungan agamaagama agar mereka mampu melakukan pencerahan dan proses deradikalisasi pemahaman al-Qur'an dan hadits menuju paham yang humanis dan terbuka dan penuh perdamaian. Dengan melakukan deradikalisasi maka perlahan stigma negatif itu akan hilang dan muncul pemahaman baru mengenai Islam sebagai rahmatan lil'alamin. Para pendakwah Islam mesti mampu menempatkan diri sebagai motivator, sebagai pembawa pesan kedamaian dan ketentraman, dan bukannya memperkeruh keadaaan dengan menunjukkan sikap yang keras dan tertutup, apalagi menjadi provokator umat sehingga umat terpecah-belah. Inilah tantangan kehidupan beragama di abad ke-21, abad yang penuh kebebasan informasi! 


\section{Daftar Pustaka}

Abdurrahman Wahid (ed), Ilusi Negara Islam: Ekspansi Gerakan Islam Transnasional di Indonesia, Jakarta: The Wahid Institute, AlMaa'rif, Gerakan Bhineka Tunggal Ika, 2009

A. Fadlan, Islam dan Radikalisme di Indonesia, Jakarta: LIPI Press, 2005. Ariel Heryanto, Identitas dan Kenikmatan, Jakarta: KPG, 2015.

Azyumardi Azra, "Mereka Mengambil Alih Penegakan Hukum", Republike 2 Maret 2002

Bachtiar Effendi, Radikalisme: Sebuah Pengantar, Jakarta: PPIM IAIN, 1998.

Budhy Munawar-Rachman, Sekularisme, Liberalisme dan Pluralisme, Jakarta: Grasindo, 2010.

Deny Suwito, Radikalisme di Dunia Islam, Jakarta: CMM, 2005.

Hamid Algar, Wabhabisme: Sebuah Tinjauan Kritis, terj. Rudy harisyah Alam, Jakarta: Paramadina, 2005.

Husein Muhammad, Mengaji Pluralisme Kepada Mahaguru Pencerahan, Bandung: Mizan, 2011.

Karlina Supelli, Dari Kosmologi ke Dialog: Mengenal batas Pengetabuan, Menentang Fanatisme, Bandung: Mizan, 2011.

Karen Amstrong, Berperang Demi Tuhan: Fundamentalisme dalam islam, Kristen, dan Yahudi, terj. T. hermaya, Mizan, Bandung, 2013

Larry May, Shari Collins-Chobanian dan Kai Wong (ed), Etika Terapan: Sebuab Pendekatan Multikultural, Terj. Imron Rosyidi, Yogyakarta: Tiara Wacana, 2001.

Martin van Bruinnessen (ed), Coservative Turn: Islam Indonesia dalam Ancaman Fundamentalisme, Bandung: Mizan, 2014.

Nasaruddin Umar, Deradikalisasi Pemahaman Al-Qur'an dan Hadis, Jakarta: PT Elex Media Komputindo, 2014.

Lampung Post, "Organisasi Anti Pancasila Ancam NKRI”, Rabu 11 Mei 2016 
Kompas, "Bin dan Kepolisian terus Mengawasi Gerakan Radikal di Indonesia", Kompas Senin 16 Mei 2016

Republika, "Radikalisme dan Komunisme Tetap sebagai bahaya laten", Senin 16 Mei 2016 
Andi Eka Putra 